\title{
Analisis Hubungan Sarana, Pengetahuan dan Sikap Bidan Praktik Mandiri dengan Kepatuhan Menjalankan Standar Pelayanan Antenatal Care di Kota Padangsidimpuan Tahun 2019
}

\begin{abstract}
Evi Erianty Hasibuan ${ }^{1,2}$
${ }^{1}$ Magister Program Institut Kesehatan DELI HUSADA Deli Tua,

${ }^{2}$ Lecture Of Program Institut Kesehatan DELI HUDASA Deli Tua.

Info Artikel

Article history:

Diterima 19-06-2021

Revisi 29-06-2021

Disetujui 27-07-2021

\section{Kata kunci:}

Kepatuhan,

Bidan Praktik Mandiri,

Standar Pelayanan Antenatal care.

A B S T R A K

Antenatal care merupakan pelayanan yang di berikan pada ibu hamil untuk monitor, mendukung kesehatan ibu dan mendeteksi ibu apakah ibu hamil normal atau bermasalah. Menurut WHO, secara global lebih dari $70 \%$ kematian ibu disebabkan oleh komplikasi kehamilan dan persalinan seperti haemorrhage, hipertensi, sepsis dan aborsi. Berdasarkan data yang diperoleh dari profil dinas kesehatan provinsi Sumatera Utara tahun 2017, dikota Padangsidimpuan pada tahun 2017 cakupan kunjungan ANC mencapai $(76,58 \%)$ dan belum mencapai target sesuai dengan Renstra Dinas Kesehatan Provinsi Sumatera Utara Tahun 2017 sebanyak (95\%). Jenis Penelitian adalah penelitian observasional analitik dengan desain cross sectional. Populasi dalam penelitian ini adalah bidan praktik mandiri yang ada dikota padangsidimpuan, sampel dalam penelitian ini berjumlah 102 responden. Tehnik pengumpulan data menggunakan kuesioner dan analisis data menggunakan analisis univariat, bivariat dan multi variat dengan analisis regresi logistik. Berdasarkan analisis bivariat menunjukkan ada hubungan sarana, pengetahuan dan sikap bidan praktik mandiri dengan kepatuhan menjalankan standar pelayanan antenatal care dengan nilai $\mathrm{p}<0,05$. Hasil penelitian dengan analisis multivariat logistik regresi menunjukkan faktor yang berhubungan dengan kepatuhan bidan praktik mandiri dalam menjalankan standar pelayanan antental care adalah sikap dengan nilai $(\mathrm{p}=$ $0,026)$.
\end{abstract}

This is an open access article under the CC BY-SA license.

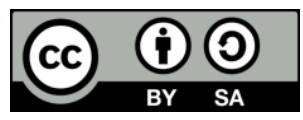

\section{Koresponden Penulis:}

Evi Erianty Hasibuan,

Program Studi Diploma III Kebidanan, Institut Teknologi dan Kesehatan Sumatera Utara,

Jl. Trans Sumatera Bukittinggi - Padang Sidempuan, Sihitang, Padangsidimpuan Tenggara, Kota Padang

Sidempuan, Sumatera Utara 22733.

Email: evi.akhmad@gmail.com

\section{PENDAHULUAN}

Antenatal care merupakan pelayanan yang di berikan pada ibu hamil untuk monitor, mendukung kesehatan ibu dan mendeteksi ibu apakah ibu hamil normal atau bermasalah. Kehamilan melibatkan perubahan fisik maupun emosional dari ibu serta perubahan sosial dalam keluarga, memantau perubahan - perubahan fisik yang normal yang dialami ibu serta tumbuh kembang janin, juga mendeteksi dan serta menatalaksanan kondisi yang tidak normal dan menghasilkan kelahiran bayi yang cukup bulan. Oleh karena itu pelayanan/asuhan antenatal merupakan cara penting untuk memonitor dan mendukung kesehatan ibu hamil normal dan mendeteksi ibu dengan kehamilan normal. Ibu hamil di anjurkan mengujungi dokter atau bidan sedini mungkin semenjak ia merasa dirinya hamil dan mendapatkan pelayanan/asuhan antenatal. (Ai yeyen Rukiah, 2009). 
Di Indonesia, Selama tahun 2006 sampai tahun 2017 cakupan pelayanan kesehatan ibu hamil K4 cenderung meningkat. Jika dibandingkan dengan target Renstra Kementerian Kesehatan RI tahun 2017 yang sebesar 76\%, capaian tahun 2017 telah mencapai target tahun tersebut walaupun masih terdapat 11 provinsi yang belum mencapai target. Adapun provinsi yang belum memenuhi target sesuai dengan Renstra Kementerian Kesehatan RI tahun 2017 antara lain Provinsi Sulawesi Tengah $(73,20 \%)$, Provinsi Sulawesi Barat (67,77\%), Provinsi Sulawesi Utara (63,17\%), Provinsi Maluku ( $58,63 \%)$. Provinsi Maluku Utara (55,44 \%), Provinsi Nusa Tenggara Timur ( 47,62\%), Provinsi Papua $(43,82 \%)$, Provinsi Papua Barat $(23,19 \%)$. Kendala yang dihadapi dalam pelaksanaan pelayanan kesehatan ibu hamil tidak hanya dari sisi akses. Kualitas pelayanan yang diberikan juga harus ditingkatkan, diantaranya pemenuhan semua komponen pelayanan kesehatan ibu hamil harus diberikan saat kunjungan.Dalam hal ketersediaan sarana kesehatan, hingga bulan Desember 2017, terdapat 9.825 puskesmas. Keberadaan puskesmas secara ideal harus didukung dengan aksesibilitas yang baik. Hal ini tentu saja sangat berkaitan dengan aspek geografis dan kemudahan sarana dan prasarana transportasi. Dalam mendukung penjangkauan terhadap masyarakat di wilayah kerjanya, puskesmas juga sudah menerapkan konsep satelit dengan menyediakan puskesmas pembantu, (Profil Kesehatan RI, 2017 ).

Berdasarkan data yang di peroleh dari profil kesehatan kota Padangsidimpuan Tahun (2017), angka kematian bayi sebanyak 29 dari 3.737 kelahiran. Ada beberapa hal yang mempengaruhi Angka Kematian Bayi secara umum adalah tingkat kesakitan, status gizi, kesehatan ibu hamil dan proses penanganan persalinan. Gangguan perinatal merupakan salah satu dari sekian faktor yang mempengaruhi perkembangan fungsi dan organ janin, (Profil Kesehatan Kota Padangsidimpuan Tahun 2017).

Berdasarkan penelitian yang Fitrayeni, diterbitkan di jurnal kesehatan masyarakat Andalas Tahun 2015.Kunjungan ANC tidak lengkap banyak terdapat pada responden dengan peran bidan kurang baik (80\%) dibandingkan dengan peran bidan yang baik $(34,6 \%)$. Hasil analisis bivariat diketahui ada hubungan yang bermakna antara peran bidan dengan kelengkapan kunjungan ANC (pvalue $=0,003$ ). Diketahui nilai ratio prevalency sebesar 2,23. Berarti variabel peran bidan merupakan salah satu faktor risiko dalam kelengkapan kunjungan ANC pada ibu hamil. Ibu yang memperoleh peran bidan yang kurang baik 2,23 kali berisiko melakukan kunjungan ANC tidak lengkap dibanding ibu yang memperoleh peran bidan yang baik pada saat kunjungan ANC. Serupa dengan hasil Herianti bahwa terdapat hubungan yang bermakna peran tenaga kesehatan dengan kunjungan ulang pemeriksaan kehamilan K4. Bidan memiliki peran dan fungsi dalam asuhan kebidanan baik pada individu, kelompok, maupun masyarakat.Salah satu indikator keberhasilan peranannya dilihat dari Cakupan ANC. Dalam ANC, bidan melaksanakan perannya pada ibu hamil, keluarga dan komunitas.Untuk sangat perlu ditingkatkan dukungan terhadap peranan bidan, $\square$ Fitrayeni,2015 $\square$.

Berdasarkan survey singkat yang dilakukan peneliti pada bulan desember 2018, terkait kepatuhan BPMterhadap standar pelayanan ANC di Kota Padangsidimpuan terhadap 15 bidan desa yang ada di Kota Padangsidimpuan, bidan mengetahui dan mengerti tentang standar pelayanan ANC tetapi belum melaksanakan standar pelayanan antenatal care sepenuhnya karena berbagai alasan diantaranya kurangnya sarana dan prasarana dan tidak memahami sepenunya pentingnya pelayanan ANC yang dilakukan dengan sesuai standar.

Padahal salah satu upaya untuk menurunkan AKI/AKB yang merupakan masalah kesehatan yang sangat serius yang harus di tanggulangi dengan baik adalah dengan melakukan standar pelayanan ANC dengan baik guna untuk mendeteksi secara dini penyulit dan komplikasi kehamilan yang di alami seorang ibu.

Berdasarkan latar belakang tersebut diatas maka dari itu peneliti sadar betul bahwa perlu untuk melakukan penelitian tentang analisis hubungan sarana, pengetahuan, dan sikap bidan praktik mandiri dengan kepatuhan menjalankan standar pelayanan Antenatal Care di Kota Padangsidimpuan Tahun 2019.

\section{METODE PENELITIAN}

Jenis penelitian bersifat deskriptif analitik dengan pendekatan crosssectional. Penelitian ini dilaksanakan di seluruh bidan praktik mandiri yang ada di Kota Padangsidimpuan waktu penelitian dilakukan pada bulan maret. Populasi dalam penelitian ini adalah bidan praktik mandiri yang ada di Kota Padangsidimpuan, besar sampel adalah 102 sampel. Dalam penelitian ini metode analisa yang 
dilakukan analisa univariat, analisa bivariat (menggunakan uji chi-square) dan analisa multivariat( menggunakan regresi logistic).

\section{HASIL DAN PEMBAHASAN}

Tabel 1. Distribusi Frekuensi Karakteristik Responden Bidan Praktik Swasta di Kota Padangsidimpuan

\begin{tabular}{lcc}
\multicolumn{2}{c}{ Tahun 2019 } \\
& & \\
\hline Umur & Frekuensi & Persentase (\%) \\
20 - 40 Tahun & 28 & \\
41 - 60 Tahun & 64 & 62,7 \\
61 - 80 Tahun & 10 & 9,8 \\
\hline Lama Bekerja & & \\
1 Tahun & 25 & 24,5 \\
1-2 Tahun & 67 & 65,7 \\
> Tahun & 10 & 9,8 \\
\hline Pendidikan & & \\
D III & 83 & 81,4 \\
D IV & 13 & 12,7 \\
S1 & 6 & 5,9 \\
\hline
\end{tabular}

Berdasarkan tabel 1 di atas dapat dilihat bahwa distribusi responden berdasarkan umur 20-40 tahun sebanyak 28 orang $(27,5 \%)$, pada rentang usia $41-60$ tahun sebanyak 68 orang $(62,7 \%)$, dan usia $61-80$ tahun 10 orang $(9,8 \%)$. Berdasarkan lama bekerja $<1$ tahun sebanyak 25 tahun $(24,5 \%)$, lama bekerja $1-2$ tahun sebanyak Berdasarkan tingkat pendidikan diketahui responden dengan tingkat pendidikan D3 sebanyak 83 orang $(81,4 \%)$, D IV sebanyak 13 orang $(5,9 \%)$. Dan S1 sebanyak 6 orang $(5,9 \%)$.

Tabel 2. Proporsi Responden berdasarkan sarana, pengetahuan dan sikap dalam menjalankan standar

\begin{tabular}{lcc}
\multicolumn{3}{l}{ pelayanan antenatal care di kota Padangsidimpuan tahun 2019} \\
\hline Variabel Independen & Frekuensi & Proporsi \\
\hline Sarana & & \\
Tidak Cukup & 57 & $55,9 \%$ \\
Cukup & 45 & $44,1 \%$ \\
\hline Pengetahuan & & \\
Kurang baik & 56 & $54,9 \%$ \\
Baik & 46 & $45,1 \%$ \\
\hline Sikaf & & \\
Negati & 62 & $60,8 \%$ \\
Positif & 40 & $39,2 \%$ \\
\hline Kepatuahan & & \\
Tidah patuh & 55 & $53,9 \%$ \\
Patuh & 47 & $46,1 \%$ \\
\hline \multicolumn{1}{c}{$\mathrm{n}$} & 102 & $100 \%$
\end{tabular}

Berdasarkan hasil tabel 2 di atas dapat diketahui bahwa variabel sarana tidak cukup sebanyak 57 $(55,9 \%)$ orang, sarana cukup sebanyak $45(44,1 \%)$, variabel pengetahuan kurang sebanyak 56 $(54,9 \%)$ dan pengetahuan baik sebanyak $46(45,1 \%)$ variabel sikap negatif sebanyak $62(60,8 \%)$ dan sikap positif sebanyak $40(39,2 \%)$ dan variabel kepatuhan dalam menjalankan standar pelayanan antenatal care tidak patuh sebanyak $55(53,9 \%)$ dan patuh sebanyak $47(46,1 \%)$. 
Tabel 3. Hubungan antara sarana dengan kepatuhan Bidan praktik mandiri dalam menjalankan standar pelayanan antenatal care

\begin{tabular}{|c|c|c|c|c|c|c|c|c|}
\hline \multirow[t]{2}{*}{ Sarana } & & $\begin{array}{l}\text { Kep } \\
\text { ienj } \\
\text { St } \\
\text { pela } \\
\text { ten } \\
\text { ak } \\
\text { uh }\end{array}$ & $\begin{array}{l}\text { tuh } \\
\text { lan } \\
\text { ada } \\
\text { ans } \\
\text { tal }\end{array}$ & & & v & \multirow[t]{2}{*}{$\begin{array}{c}P \\
\text { value }\end{array}$} & \multirow[t]{2}{*}{$\begin{array}{c}\text { RP } \\
(95 \% \text { CI })\end{array}$} \\
\hline & f & $\%$ & f & $\%$ & $\mathbf{f}$ & $\%$ & & \\
\hline $\begin{array}{l}\text { Tidak } \\
\text { cukup }\end{array}$ & $\begin{array}{l}3 \\
7\end{array}$ & $\begin{array}{l}6 \\
4, \\
9\end{array}$ & $\begin{array}{l}2 \\
0\end{array}$ & $\begin{array}{c}35, \\
1\end{array}$ & $\begin{array}{l}5 \\
7\end{array}$ & $\begin{array}{l}1 \\
0 \\
0\end{array}$ & 0,021 & $\begin{array}{r}1,623 \\
(1,082-\end{array}$ \\
\hline Cukup & $\begin{array}{l}1 \\
8\end{array}$ & $\begin{array}{l}4 \\
0\end{array}$ & $\begin{array}{l}2 \\
7\end{array}$ & 60 & $\begin{array}{l}4 \\
5\end{array}$ & $\begin{array}{l}1 \\
0 \\
0\end{array}$ & & $2,438)$ \\
\hline
\end{tabular}

Dari tabel 3 di atas dapat dilihat daridari 57 Bidan praktik mandiri yang memiliki sarana tidak cukup terdapat $37(64,9 \%)$ yang tidak patuh menjalankan satandar pelayanan antenatal care. Kemudian dari 45 bidan praktik mandiri yang memiliki sarana cukup terdapat 18 (40\%) yang tidak patuh dalan menjalankan standar pelayanan antenatal care.

Berdasarkan analisis statistik dengan menggunakan uji chi - square diketahui nilai $p<0,05$ yang artinya ada hubungan sarana dengan ketidakpatuhan Bidan praktik mandiri dalam menjalankan standar pelayanan antenatal care di Kota Padangsidimpuan tahun 2019 Dengan RP sebesar 1,623 $(1,082-2,438)$ maka disimpulkan bahwa Bidan praktik mandiri yang memiliki sarana cukup 1,62 kali lebih besar memiliki kepatuhan dalam menjalankan satndar pelayanan antenatal care. Pada analisis multivariat variabel independent sarana tidak dominan berhubungan dengan ketidakpatuhan bidan dalam menjalankan standar pelayanan antenatal care. Hal ini terjadi karena bidan praktik mandiri kemungkinan merasa tidak perlu menggunakan sarana yang dimiliki untuk melakukan pemeriksaan antenatal care.

Misalnya dalam pemeriksaan haemoglobin, bidan praktik mandiri memiliki alat untuk mengukur jumlah kadar haemoglobin dalam darah dengan menggunakan alat HB Sahli, tetapi kenyataan yang peneliti temukan di lapangan mayoritas responden tidak menggunakan alat tersebut untuk mengukur tekanan darah haemoglobin dalam darah ibu hamil, karena responden sudah merasa cukup dengan hanya melakukan pemeriksaan konjungtiva mata pasien dan mengetahui pasien anemia atau tidak.

Tabel 4. Hubungan antara Pengetahuan dengan kepatuhan Bidan praktik mandiri dalam menjalankan standar pelayanan antenatal care

\begin{tabular}{|c|c|c|c|c|c|c|c|c|}
\hline \multirow{3}{*}{$\begin{array}{l}\text { Penget } \\
\text { ahuan }\end{array}$} & \multicolumn{4}{|c|}{$\begin{array}{c}\text { Kepatuhan } \\
\text { menjalankan } \\
\text { Standar pelayanan } \\
\text { antenatal care }\end{array}$} & \multirow{2}{*}{\multicolumn{2}{|c|}{$\mathbf{N}$}} & \multirow{3}{*}{$\begin{array}{c}P \\
\text { val } \\
\text { ue }\end{array}$} & \multirow{3}{*}{$\begin{array}{c}\text { RP } \\
(95 \% \\
\text { CI })\end{array}$} \\
\hline & \multicolumn{2}{|c|}{$\begin{array}{c}\text { Tidak } \\
\text { Patuh }\end{array}$} & \multicolumn{2}{|c|}{ Patuh } & & & & \\
\hline & f & $\%$ & $\mathbf{f}$ & $\%$ & f & $\%$ & & \\
\hline $\begin{array}{l}\text { Kurang } \\
\text { baik }\end{array}$ & 36 & 64,3 & 20 & $\begin{array}{c}36 \\
, 7\end{array}$ & 56 & $\begin{array}{c}10 \\
0\end{array}$ & 0,03 & 1,556 \\
\hline Baik & 19 & 41,3 & 27 & $\begin{array}{c}58 \\
, 7\end{array}$ & 46 & $\begin{array}{c}10 \\
0\end{array}$ & 4 & $2,312)$ \\
\hline
\end{tabular}

Berdasarkan tabel 4 di atas dapat dilihat bahwadari 56 Bidan praktik mandiri yang memiliki pengetahuan kurang baik terdapat $36(64,3 \%)$ orang responden yang tidak patuh dalam menjalank an 
standar pelayanan antenatal care. Kemudian dari 46 responden berpengetahuan baik terdapat 19 $(41,3 \%)$ oranng responden yang tidak patuh dalam menjalankan standar pelayanan antenatal care.

Berdasarkan analisis statistik dengan menggunakan uji chi - square nilai $\mathrm{p}<0,05$ yang artinya ada hubungan pengetahuan dengan ketidakpatuhan Bidan praktik mandiri dalam menjalankan standar pelayanan antenatal care di Kota Padangsidimpuan tahun 2019. Dengan RP sebesar 1,556 $(1,048$ - 2,312) maka disimpulkan bahwa Bidan praktik mandiri yang memiliki pengetahuan baik 1,55 kali lebih besar memiliki kepatuhan dalam menjalankan satndar pelayanan antenatal care. Menurut Teori L Green prilaku juga dipengaruhi oleh faktor pendukung (enabling factor) yang mencakup lingkungan fisik, tersedia atau tidak tersedianya fasilitas atau sarana pendukung dalam melaksanakan pelayanan ANC oleh bidan. Bidan dalam penelitian ini melakukan prilaku tidak patuh terhadap pelaksanaan standar pelayanan ANC disebabkan karena kurang lengkapnya peralatan yang dibutuhkan untuk pelaksanaan pelayanan ANC disebabkan karena kurang kelengkapan peralatan yang dibutuhkan untuk pelaksanaan pelayanan ANC yaitu peralatan untuk pemeriksaan laboratium. Menurut peneliti pengetahuan bidan merupakan salah satu faktor yang mendukung dalam tercapainya cakupan pelayanan kebidanan salah satunya mengetahui tentang standar pelayanan antenatal care. tetapi pengetahuan yang baik juga belum tentu berhubungan dengan ketidakpatuhan standar pelayanan antenatal care kepada pasien.

Berdasarkan hasil penelitian dapat disimpulkan bahwa pengetahuan baik berhubungan dengan ketidakpatuhan bidan praktik mandiri dalam menjalankan standara pelayanan antenatal care. Hal ini kemungkinan disebabkan olah beberapa faktor misalnya faktor kebiasaan responden. Responden tahu tentang standar pelayanan antenatal care tetapi tidak dijalankan saat melakukan pemeriksaan antental care, karena responden menganggap bahwa pemeriksaan tekanan darah, pemeriksaan DJJ, pemeriksan Leopold dan pemeriksaan tablet FE sudah cukup dilakukan dalam pemeriksaan antenatal care.

Tabel 5. Hubungan antara sikap dengan kepatuhan Bidan praktik mandiri dalam menjalankan standar pelayanan antenatal care

\begin{tabular}{|c|c|c|c|c|c|c|c|c|}
\hline \multirow[t]{3}{*}{ sikap } & \multicolumn{4}{|c|}{$\begin{array}{c}\text { Kepatuhan } \\
\text { menjalankan Standar } \\
\text { pelayanan antenatal } \\
\text { care }\end{array}$} & \multirow{2}{*}{\multicolumn{2}{|c|}{$\mathbf{n}$}} & \multirow{3}{*}{$\begin{array}{c}P \\
\text { value }\end{array}$} & \multirow{3}{*}{$\begin{array}{c}\text { RP } \\
(95 \% \mathrm{CI})\end{array}$} \\
\hline & \multicolumn{2}{|c|}{$\begin{array}{l}\text { Tidak } \\
\text { Patuh }\end{array}$} & \multicolumn{2}{|c|}{ Patuh } & & & & \\
\hline & f & $\%$ & f & $\%$ & f & $\%$ & & \\
\hline Negatif & 41 & 66,1 & 21 & 33,9 & 62 & 100 & 0004 & 1,889 \\
\hline Positif & 14 & 41,3 & 26 & 58,7 & 40 & 100 & & $(1,195-2,988$ \\
\hline
\end{tabular}

Berdasarkan tabel 5 di atas dapat diketahui bahwa dari 62 bidan praktik mandiri yang memiliki sikap negatif dalam menjalankan standar pelayanan antenatal care terdapat $41(66,1 \%)$ orang responden yang tidak patuh dalam menjalankan standar pelayanan antenatal care. Kemudian dari 40 bidan praktik mandiri yang memilki sikap positif terdapat $14(41,3 \%)$ orang responden yang tidak patuh dalam menjalankan standar pelayanan antenatal care.

Kemudian Berdasarkan analisis statistik dengan menggunakan uji chi - square nilai $p<0,05$ yang artinya ada hubungan sarana dengan ketidakpatuhan Bidan praktik mandiri dalam menjalankan standar pelayanan antenatal care di Kota Padangsidimpuan tahun 2019. Dengan RP sebesar 1,889 $(1,195$ - 2,988) maka disimpulkan bahwa Bidan praktik mandiri yang memiliki sikap positif 1,88 kali lebih besar memiliki kepatuhan dalam menjalankan satndar pelayanan antenatal care.

Sikap terdiri dari beberapa tingkat yaitu menerima, merespon, menghargai dan bertanggung jawab, (Notoadmodjo 2010). Begitu juga sikap Bidan praktik mandiri tentang kepatuhan menjalankan standar pelayanan antenatal care dapat di bentuk dari pemahaman Bidan tentang pentingnya melakukan standar pelayanan antenatal care sehingga terlaksanakannya pelayanan antenatal care yang optimal dan berkualitas.

Menurut penelitian, sikap yang dimilki bidan praktik mandiri berhubungan dengan pelaksanaan standar pelayanan antenatal care, dimana dari hasil penelitian diperoleh bahwa sebagian besar bidan yang bersikap negatif tidak patuh dalam menjalankan standar pelayanan antenatal care. 
hal ini disebabkan oleh karena kurangnya kesadaran bidan praktik mandiri tentang pentingnya pelayanan antenatal careyang sesuai standar, jadi peneliti melihat selamanya selama ibu hamil tidak memiliki keluhan selama kehamilan tidak perlu dilakukan pemeriksaan antenatal care sesuai standar. Sikap bidan praktik mandiri dalam menjalankan standar pelayanan antenatal care di kota Padangsidimpuan sangat penting untuk mencapai layanan antenatal care yang unggul dan optimal. Guna menurukan angka kesakitan dan kematian ibu di kota padangsidimpuan.

Tabel 6. Langkah pertama regresi logistik ganda hubungan sarana, pengetahuan dan sikap terhadap kepatuhan Bidan praktik mandiri dalam menjalankan standar pelayanan Antenatal Care di Kota Padangsidimpuan tahun 2019

\begin{tabular}{lcccccc}
\hline \multicolumn{1}{c}{ Variabel } & \multirow{2}{*}{ Wald } & df & Sig & Rp & \multicolumn{2}{c}{ 95\% C.I Rp } \\
Independen & & & & & Lower & Upper \\
\hline Sarana & 1,720 & 1 & 0,190 & 1,818 & 0,744 & 4.444 \\
\hline Pengetahuan & 0,516 & 1 & 0,473 & 1,419 & 0,546 & 3.685 \\
\hline Sikap & 2,911 & 1 & 0,088 & 2,402 & 0,878 & 6.571 \\
\hline Constan & 5.407 & 1 & 0.020 & 0.410 & & \\
\hline
\end{tabular}

Analisis multivariat bertujuan untuk mendapatkan variabel yang berhubungan paling dominan dengan kepatuhan Bidan praktik mandiri dalam menjalankan standar pelayanan antenatal care di Kota Padangsidimpuan tahun 2019. Dalam pemodelan ini semua kandidat di cobakan secara bersama - sama, kemudian variabel yang nilai $\mathrm{p}$ value $>0,05$ akan dikeluarkan. Berdasarkan tabel 4,6 di atas dapat diketahui terdapat dua variabel yang dikeluarkan dari analisis uji regresi logistik berganda karena mempunyai $p>0,025$ yaitu pengetahuan.

Tabel 7. Hasil Akhir Uji regresi Logistik ganda hubungan hubungan sarana dan sikap terhadap kepatuhan Bidan praktik mandiri dalam menjalankan standar pelayanan Antenatal Caredi Kota Padangsidimpuan tahun 2019

\begin{tabular}{lcrrrrrrr}
\hline $\begin{array}{c}\text { Variabel } \\
\text { Independen }\end{array}$ & B & S.E & Wald & df & Sig & Rp & $\begin{array}{c}\text { 95\% C.I Rp) } \\
\text { Lower }\end{array}$ & Upper \\
\hline Sarana & 0.632 & 0.452 & 1.953 & 1 & 0.162 & 1.882 & 0.775 & 4.567 \\
\hline Sikap & 1.042 & .460 & 5.122 & 1 & 0.024 & 2.834 & 1.150 & 6.984 \\
\hline Constan & 0.820 & .367 & 4.984 & 1 & .026 & .440 & & \\
\hline
\end{tabular}

\section{KESIMPULAN}

Berdasarkan hasil analisis dan pembahasan penelitian, maka dapat diambil kesimpulan Pada analisis bivariat dari variabel independen yang berhubungan dengan kepatuhan bidan praktik dalam menjalankan standar pelayanan antenatal care adalah sikap, sedangkan variabel sarana dan pengetahuan tidak mempunyai hubungan yang signifikan.

\section{REFERENSI}

Ai yeyen Rukiah, 1. y. (2009). Asuhan Kebidanan 1 Kehamilan. Jakarta: Trans Info Media.

Fitrayeni. (2015). Penyebab Rendahnya Kelengkapan Kunjungan Antenatal Care Ibu Hamil Di Wilayah Kerja Puskesmas Pegambiran. Jurnal Kesehatan Masyarakat Andalas , 101- 107.

Indonesia, B. D. (2017). Kebidanan : Teori Dan Asuhan . Jakarta: Penerbit Buku Kedokteran EGC.

Indonesia, K. K. (2017). Peraturan Mentri Kesehatan Republik Indonesia Nomor 28 Tahun 2017. Jakarta: Kementrian Kesehatan Republik Indonesia.

Indonesia, K. K. (2016). Peraturan Mentri Kesehatan Republik Indonesia No 43 Tahun 2016 Tentang Standar Pelayanan Minimal Bidan Kesehatan. Jakarta: Kementrian Kesehatan Republik Indonesia.

Indonesia, P. D. (2014). Situasi Bidan Di Indonesia. Jakarta: Kementrian Kesehatan Republik Indonesia.

Library, U. I. (2007). Faktor-faktor yang berhubungan dengan kepatuhan bidan di Desa terhadap standar layanan Antenatal (ANC) di Kabupaten Muaro Jambi tahun 2007. Universitas Indonesia Library .

Mufdilillah. (2009). Panduan Asuhan Kebidanan Ibu Hamil. Jogjakarta: Nuha Medika.

Multasih, T. (2017). Faktor-faktor yang berhubungan dengan kepatuhan pelaksanaan standar pelayanan antenatal care oleh bidan praktik mandiri (bpm) dengan wilayah aki tinggi di kabupaten boyolali. Universitas muhammadiyah surakarta , 30-32.

Notoatmodjo, S. (2007). Promosi Kesehatan Dan Teori - teori Kesehatan . Jakarta: Rineka Cifta.

Organization, W. H. (2016). Standards for improving quality of maternal and newborn care in health facilities. Geneva, Switzerland.: WHO Document Production Services.

Pangalila, M. C. (2016). Analisis Kinerja Bidan Dalam Pelayanan Antenatal Pada Puskesmas Di Kabupaten Minahasa Utara. Universitas Sam Ratulangi , 50-56. 
RI., K. K. (2017). Profil Kesehatan Indonesia Tahun 2017. Jakarta: Kementerian Kesehatan Republik Indonesia.

Romauli, S. (2011). Asuhan Kebidanan 1 (Konsp Dasar Asuhan Kehamilan . Yogyakarta: Nuha Medika.

Sri, W. (2018). Faktor - Faktor yang mempengaruhi Kepatuhan bidan Terhadap Standar Pelayanan Antebatal di kota palembang. jurnal Universias Sriwijaya, 96- 107.

Utara, D. K. (2017). Profil Kesehatan Sumatera Utara tahun 2017. Medan: Dinas Kesehatan Sumatera Utara.

Wulandari, A. (2017). Analisis Pelayanan Antenatal care dan faktor - faktor yang berkaitan dengan cakupan Pelayanan Antental CareOleh Bidan Desa Di Kabupaten Jember. Jurnal Kesehatan Masyarakat FKM UNDIP , http://ejuornal-s1.UNDIP.ac.id/indeks.php/jkm. 